\title{
Synthesis of 2,4-Disubstituted Thiophenols and Solid State Structures of Thiocarbamate Precursors
}

\author{
Aarón Flores-Figueroa, Víctor Arista-M., Daniel Talancón-Sánchez and Ivan Castillo* \\ Instituto de Química, Universidad Nacional Autónoma de México, Circuito Exterior, Ciudad Universitaria, \\ 04510 México D.F., México
}

\begin{abstract}
Uma série de tiofenóis com diferentes orto-substituintes, 2,4-dimetiltiofenol, 2-terc-butil-4metiltiofenol e 2-(1-adamantil)-4-metiltiofenol, os quais mostram diferentes graus de impedimento estérico na posição 2, foram preparados a partir dos correspondentes fenóis. Uma despronotação inicial dos fenóis foi obtida com o uso de $\mathrm{NaH}$ em dimetoxietano, seguido de tratamento com cloreto de $N, N$-dimetiltiocarbomoila, obtendo-se os $O$-ariltiocarbamatos. A termólise destes compostos resultou num rearranjo, obtendo-se os $S$-ariltiocarbamatos. Finalmente, a redução dos $S$ ariltiocarbamatos com $\mathrm{LiAlH}_{4}$ em THF, seguido de acidificação, levou ao isolamento dos tiofenóis. Todos os produtos foram caracterizados por técnicas espectroscópicas, e para alguns tiocarbamatos a estrutura sólida foi determinada por difração de raio X.
\end{abstract}

A series of thiophenols with different ortho-substituents, 2,4-dimethylthiophenol, 2-tert-butyl4-methylthiophenol, and 2-(1-adamantyl)-4-methylthiophenol, which display varying degrees of steric hindrance on the 2-position, was prepared from the corresponding phenols. Initial deprotonation of the phenols was achieved with $\mathrm{NaH}$ in dimethoxyethane, followed by treatment with $\mathrm{N}, \mathrm{N}$ dimethylthiocarbamoyl chloride, to obtain the $O$-arylthiocarbamates. Thermolysis of the latter compounds resulted in rearrangement, which yields the desired $S$-arylthiocarbamates. Finally, reduction of the $S$-arylthiocarbamates with $\mathrm{LiAlH}_{4}$ in THF, followed by acidic workup, allowed the isolation of the thiophenols. All products were characterized by spectroscopic techniques, and in the case of some of the thiocarbamates the solid state structures were determined by single-crystal X-ray diffraction.

Keywords: thiols, thiophenols, thiocarbamates, bulky thiols, X-ray structure

\section{Introduction}

Thiols represent an important class of compounds due to their relevance in organic, inorganic, and materials chemistry. ${ }^{1-3}$ Within the context of inorganic chemistry, thiols have a crucial role as thiolate ligands in coordination compounds that are relevant in both chemical and biological systems. ${ }^{2,4}$ While in many of these systems it is desirable to have bridging thiolate ligands for building multimetallic assemblies, ${ }^{5}$ in other cases sterically demanding thiols are necessary for the preparation of monometallic complexes. ${ }^{6}$ This latter situation requires thiols that can create a protective pocket around the metal center in order to avoid the formation of high nuclearity species.

The most common method of preparation of thiophenols that are not commercially available involves the lithiation of aromatic halides under an inert

\footnotetext{
* e-mail: joseivan@servidor.unam.mx
}

atmosphere. Subsequent reaction of the organolithium compounds with elemental sulfur produces the corresponding thiols upon hydrolysis. ${ }^{1}$ This method is limited by the availability of halogenated aromatic compounds required for the lithium-halogen exchange reaction, with the more widely available phenols as an alternative starting material for the synthesis of thiophenols.

Newman and Karnes developed a method for the transformation of phenols into thiophenols, ${ }^{7}$ which involves the thermal rearrangement of $O$-arylthiocarbamates into $S$-arylthiocarbamates (Scheme 1). Thus, this methodology requires the synthesis, isolation, and characterization of both $O$ - and $S$-arylthiocarbamates. Given the large number of ortho- substituted phenols that are commercially available, we decided to undertake the preparation of the corresponding thiophenols. The phenols considered in this work include 2,4-dimethylphenol (1), 2-tert-butyl-4-methylphenol (2), and 2-(1-adamantyl)-4- 


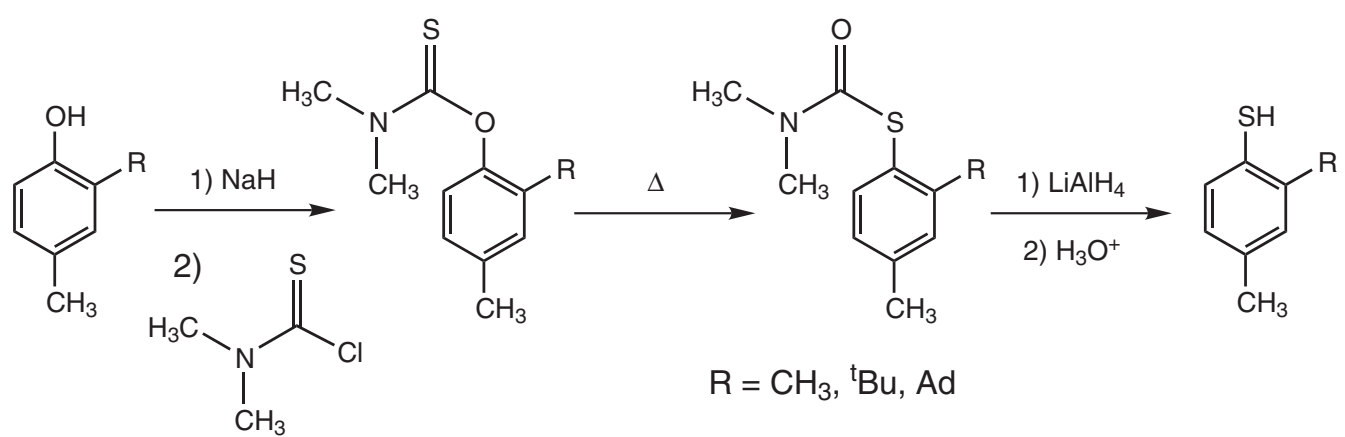

Scheme 1. Synthesis of 2,4-disubstituted thiophenols.

methylphenol (3), which can be compared in terms of their reactivity based on the varying degrees of steric hindrance provided by the substituent adjacent to the hydroxy or thiol groups.

\section{Results and Discussion}

\section{Synthesis of O-arylthiocarbamates}

2-alkyl-4-methylphenyl- $N, N$-dimethy $1-O$ thiocarbamates (alkyl $=$ methyl, tert-butyl, and 1-adamantyl) were prepared from the corresponding phenols by adapting the previously described procedure. ${ }^{7}$ The phenol with the sterically encumbering 1-adamantyl group required the longest times for the reaction to proceed to completion.

The products were characterized by standard spectroscopic techniques: Nuclear Magnetic Resonance $\left({ }^{1} \mathrm{H}\right.$ and ${ }^{13} \mathrm{C}$ NMR), infrared (IR), and electron-ionization mass spectrometry (EI-MS), as well as melting point determinations and combustion analysis. The main feature in the ${ }^{1} \mathrm{H}$ NMR spectra is the presence of two sharp singlets in a 1:1 ratio, which correspond to the $N$-methyl groups of the thiocarbamoyl moiety. The non-equivalency of the nitrogenbound methyl groups has been previously reported for related compounds. ${ }^{8}$ In this series the presence of non-equivalent $\mathrm{N}$-methyl groups was observed even for 2,4-dimethylphenyl$N, N$-dimethyl- $O$-thiocarbamate (4), which features the smallest substituent in the 2-position. It is therefore reasonable to assume that, in solution, the restriction in the rotation about the $\mathrm{C}\left(\mathrm{sp}^{2}\right)-\mathrm{N}$ bond is electronic in nature. The two $N$-methyl resonances appear at $\delta 3.34$ and $3.45 \mathrm{ppm}$, with those for 2tert-butyl-4-methylphenyl- $N, N$-dimethyl- $O$-thiocarbamate (5) at $\delta 3.39$ and $3.49 \mathrm{ppm}$, and those for 2-(1-adamantyl)-4methylphenyl- $N, N$-dimethyl- $O$-thiocarbamate (6) at $\delta 3.42$ and 3.51 .

IR spectra exhibit a band for the $\mathrm{C}=\mathrm{S}$ stretching at 1536 , 1526 , and $1553 \mathrm{~cm}^{-1}$ for compounds $\mathbf{4}, \mathbf{5}$, and $\mathbf{6}$. This spectroscopic technique is useful for identifying the presence of the $\mathrm{C}=\mathrm{S}$ versus the $\mathrm{C}=\mathrm{O}$ group of the corresponding $S$-arylthiocarbamates, since the disappearance of the aforementioned bands is followed by the appearance of new stretching bands at higher frequencies, which correspond to the $\mathrm{C}=\mathrm{O}$ group.

\section{Synthesis of S-arylthiocarbamates}

Thermal rearrangement of the $O$-arylthiocarbamates $\mathbf{4}$, 5 , and 6 to 2,4-dimethylphenyl- $N, N$-dimethyl- $S$ thiocarbamate (7), 2-tert-butyl-4-methylphenyl- $N, N$ dimethyl-S-thiocarbamate (8), and 2-(1-adamantyl)-4methylphenyl- $N, N$-dimethyl- $S$-thiocarbamate (9), respectively, was carried out neat under reduced pressure in closed systems in order to avoid loss of starting materials by sublimation at 250,280 , and $310^{\circ} \mathrm{C}$. It is evident that as the steric bulk of the ortho-substituent increases, the reaction temperature required for the rearrangement to occur also increases.

The $S$-arylthiocarbamates were characterized by spectroscopic techniques, melting point determination, and combustion analysis. The identity of the compounds was confirmed by EI-MS, which shows the presence of the expected molecular ions. In contrast with the spectra of the $O$-arylthiocarbamates, in the ${ }^{1} \mathrm{H}$ NMR spectrum of compound 7 a pair of broad resonances that arise from the $N$-methyl groups was observed at $\delta 3.02$ and 3.11. For compounds $\mathbf{8}$ and $\mathbf{9}$, the two peaks coalesce at room temperature into a single broad resonance at $\delta 3.08$ and 3.02. As mentioned above, IR spectra clearly revealed the rearrangement of the $\mathrm{O}$ and $\mathrm{S}$ atoms. This was evidenced by the disappearance of the $\mathrm{C}=\mathrm{S}$ stretching bands, and the appearance of new intense bands in the $v(\mathrm{C}=\mathrm{O})$ region at 1654,1653 , and $1655 \mathrm{~cm}^{-1}$ for $\mathbf{7}, \mathbf{8}$, and $\mathbf{9}$.

\section{Synthesis of thiophenols}

Reduction of the $S$-arylthiocarbamates with excess $\mathrm{LiAlH}_{4}$ in anhydrous THF, followed by acidic workup yielded 2,4-dimethylbenzenethiol (10) 2-tert-butyl-4- 
methylbenzenethiol (11), and 2-(1-adamantyl)-4methylbenzenethiol (12). The thiols were obtained as yellow or colorless liquids upon evaporation of the organic solvents. Compound $\mathbf{1 0}$ was only prepared by this method to prove the feasibility of the reaction since it is a commercially available substance. An alternative synthetic procedure for $\mathbf{1 0}$ has been reported which minimizes the formation of the corresponding disulfide, although it requires the sulfonyl chloride as a starting material. ${ }^{9}$

In the ${ }^{1} \mathrm{H}$ NMR spectra of the fully characterized thiols 11 and 12, the characteristic resonance of the thiol group was observed at $\delta 3.52$ and 3.57. Likewise, the most prominent feature of the IR spectrum of $\mathbf{1 1}$ was the stretching band of the $\mathrm{S}-\mathrm{H}$ group at $2567 \mathrm{~cm}^{-1}$. In the case of 12, although the corresponding $\mathrm{S}-\mathrm{H}$ band appeared at $2564 \mathrm{~cm}^{-1}$ with low intensity, both the ${ }^{1} \mathrm{H}$ NMR and the mass spectrometry data confirm its identity. Thus, the expected molecular ions in the mass spectra of the two thiols were observed, as well as the ions of the corresponding disulfides $[\mathrm{ArSSAr}]^{+}$, which are probably formed in the ionization chamber.

\section{Solid state structures of 4,5 , and 8}

Despite 2,4-dimethylbenzenethiol being a commercially available compound, there are no reports on the synthesis and properties of the $O$ - and $S$-arylthiocarbamates. Therefore, the solid state structure of the $O$-arylthiocarbamate $\mathbf{4}$ was determined by X-ray crystallography. Crystal and structure refinement data are presented in Table 1. Monoclinic crystals of $\mathbf{4}$ (space group $\mathrm{P} 2_{1} / \mathrm{c}$ ) were obtained by slow evaporation of a concentrated $\mathrm{CH}_{2} \mathrm{Cl}_{2}$ solution. In the solid state structure of $\mathbf{4}$, the thiocarbamoyl $\pi$-system appears to be delocalized onto both $\mathrm{N}$ and $\mathrm{O}$ atoms, as evidenced by the coplanarity of $\mathrm{O} 1, \mathrm{C} 9, \mathrm{~S} 1, \mathrm{~N} 1, \mathrm{C} 10$ and $\mathrm{C} 11$. This is also reflected in the bond angles around N1 [C9-N1-C10 123.3(2) ${ }^{\circ}$, C9-N1C11 120.8(2) ${ }^{\circ}, \mathrm{C} 10-\mathrm{N} 1-\mathrm{C} 11$ 115.8(2) ${ }^{\circ}$, and O1 [C1-O1C9 $121.0(2)^{\circ}$ ], which correspond to $\mathrm{sp}^{2}$-hybridized atoms. The planarity of the thiocarbamoyl group forces short intramolecular contacts between two hydrogen atoms on the N-methyl groups, and the electronegative O1 [H10cO1 2.21 $\AA$ ] and S1 [H11a-S1 2.66 ̊] atoms.

The thiocarbamoyl moiety is diverted from the orthosubstituent, such that the aromatic and thiocarbamoyl fragments are not coplanar. This results in a close C1-S1 contact (3.00 $\AA$ ), which is a requisite for the thermal rearrangement to occur. An ORTEP view of $\mathbf{4}$ at the $40 \%$ probability level is presented in Figure 1. Selected bond lengths and angles for compounds $\mathbf{4 , 5}$, and $\mathbf{8}$ are listed in Table 2.

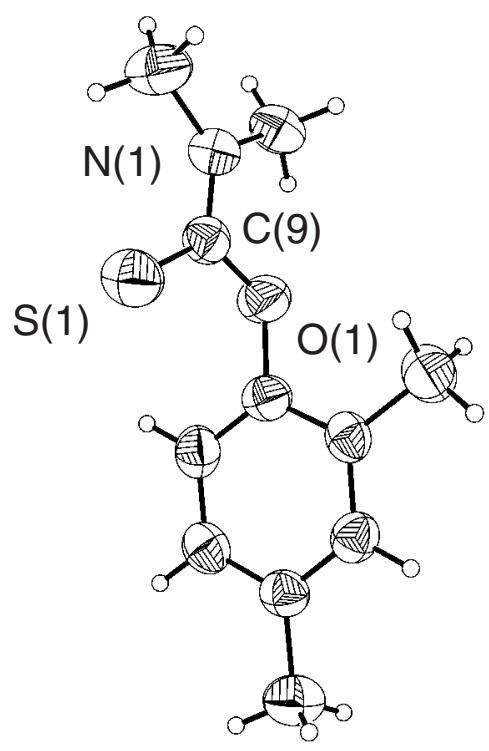

Figure 1. ORTEP view of 4.

Although we were not able to obtain the crystal structure of the corresponding $S$-arylthiocarbamate $\mathbf{7}$ for comparison of the geometric parameters with those of $\mathbf{4}$, we determined the solid state structures of $O$ - and $S$-arylthiocarbamates $\mathbf{5}$ and $\mathbf{8}$, which possess a tert-butyl ortho-substituent. Compounds $\mathbf{5}$ and $\mathbf{8}$ crystallize in the orthorhombic space group Pbca with different cell dimensions. The C12-S1 bond distance of 5 at 1.660(3) $\AA$ is comparable to that of related $O$-arylthiocarbamates. ${ }^{8,10}$ The presence of the large sulfur atom in both $O$-thiocarbamates is likely responsible for the relatively small N-C-O angles of 4 [109.7(2) ${ }^{\circ}$, and 5 [110.3(2) $\left.{ }^{\circ}\right]$. As in compound $\mathbf{4}$, the thiocarbamoyl group of 5 has $\pi$ bonding contributions from the $\mathrm{N}$ and $\mathrm{O}$ lone pairs, as evidenced in the bond angles around N1 [C12-N1-C13 121.4(2) ${ }^{\circ}, \mathrm{C} 12-\mathrm{N} 1-\mathrm{C} 14$ 123.1(2) $\left.{ }^{\circ}, \mathrm{C} 13-\mathrm{N} 1-\mathrm{C} 14115.5(2)^{\circ}\right]$ and $\mathrm{O} 1$ [C1-O1-C12 121.8(2) ${ }^{\circ}$.

Short intramolecular contacts, which are attributed to the planarity of the thiocarbamoyl group, are also present in the solid state structure of 5 [H14a-O1 2.20 A, and H13cS1 $2.52 \AA$ ]. As in $\mathbf{4}$, the thiocarbamoyl fragment of $\mathbf{5}$ is directed away from the tert-butyl substituent. This allows the $\mathrm{S} 1$ atom to make a close contact with the $\mathrm{C} 1$ atom (3.05 $\AA$ ), which is directly involved in the rearrangement reaction.

In compound $\mathbf{8}$, the carbonyl $\mathrm{C} 12-\mathrm{O} 1$ bond length of $1.210(2) \AA$ is comparable to that of related $S$-arylthiocarbamates, and it further proves the thermal rearrangement of the $\mathrm{O}$ and $\mathrm{S}$ atoms. As in the case of $\mathbf{5}$, the $S$-thiocarbamoyl fragment is planar, and directed away from the bulky ortho-substituent. A considerable amount of steric repulsion arises from the presence of the sulfur atom 
Table 1. Crystal and refinement data for compounds 4, 5 and $\mathbf{8}$

\begin{tabular}{|c|c|c|c|}
\hline & 4 & 5 & 8 \\
\hline Formula & $\mathrm{C}_{11} \mathrm{H}_{15} \mathrm{NOS}$ & $\mathrm{C}_{14} \mathrm{H}_{21} \mathrm{NOS}$ & $\mathrm{C}_{14} \mathrm{H}_{21} \mathrm{NOS}$ \\
\hline Formula weight & 209.30 & 251.38 & 251.38 \\
\hline $\mathrm{F}(000)$ & 448 & 1088 & 1088 \\
\hline Crystal size (mm) & $0.24 \times 0.19 \times 0.04$ & $0.36 \times 0.26 \times 0.22$ & $0.45 \times 0.10 \times 0.10$ \\
\hline Crystal habit & Prism & Prism & Prism \\
\hline Crystal system & Monoclinic & Orthorhombic & Orthorhombic \\
\hline Space group & $P 2_{1} / c$ & Pbca & Pbca \\
\hline$a(\AA)$ & $9.135(1)$ & $12.8815(9)$ & $8.3186(8)$ \\
\hline$b(\AA)$ & $10.278(1)$ & $12.5431(9)$ & $13.3500(13)$ \\
\hline$c(\AA)$ & $13.147(2)$ & $18.0191(13)$ & $25.895(3)$ \\
\hline$\alpha\left(^{\circ}\right)$ & 90 & 90 & 90 \\
\hline$\beta\left({ }^{\circ}\right)$ & $110.338(2)$ & 90 & 90 \\
\hline$\gamma\left({ }^{\circ}\right)$ & 90 & 90 & 90 \\
\hline$V\left(\AA^{3}\right)$ & $1157.4(2)$ & 2911.4(4) & $2875.8(5)$ \\
\hline$Z$ & 4 & 8 & 8 \\
\hline$\rho_{\text {calc }}\left(\mathrm{g} \mathrm{cm}^{-3}\right)$ & 1.201 & 1.147 & 1.161 \\
\hline$\mu\left(\mathrm{mm}^{-1}\right)$ & 0.249 & 0.208 & 0.211 \\
\hline Radiation $\operatorname{MoK} \alpha(\AA)$ & 0.71073 & 0.71073 & 0.71073 \\
\hline Diffractometer & Bruker Smart & Bruker Smart & Bruker Smart \\
\hline$\theta \min / \max \left({ }^{\circ}\right)$ & $2.38 / 24.99$ & $2.26 / 25.00$ & $1.57 / 25.00$ \\
\hline Reflections collected & 9232 & 22080 & 21868 \\
\hline Data/restr/parameters & $2031 / 0 / 131$ & $2569 / 0 / 160$ & $2530 / 0 / 160$ \\
\hline Absorption correction & None & None & None \\
\hline$R_{\text {int }}$ & 0.0653 & 0.0529 & 0.0613 \\
\hline$R^{\text {int }}$ & 0.0471 & 0.0562 & 0.0405 \\
\hline$R_{\mathrm{w}}$ & 0.0965 & 0.1356 & 0.0912 \\
\hline Goodness-of-fit on $\mathrm{F}^{2}$ & 0.910 & 0.959 & 0.935 \\
\hline Max/min peaks $\left(\mathrm{e} \AA^{-3}\right)$ & $0.227 /-0.135$ & $0.307 /-0.179$ & $0.206 /-0.155$ \\
\hline
\end{tabular}

directly bound to the aromatic ring in a position adjacent to the tert-butyl group. This is clearly reflected in the widening of the $\mathrm{S} 1-\mathrm{C} 1-\mathrm{C} 2\left[124.6(2)^{\circ}\right]$ bond angle relative to the S1-C1-C6 $\left[115.3(2)^{\circ}\right]$ angle.

Despite the planar nature of the thiocarbamoyl group, and the bond angles around the N1 atom [C12-N1-C13 118.2(2) ${ }^{\circ}, \mathrm{C} 12-\mathrm{N} 1-\mathrm{C} 14$ 125.0(2) ${ }^{\circ}, \mathrm{C} 13-\mathrm{N} 1-\mathrm{C} 14$ 116.6(2) $\left.{ }^{\circ}\right]$, which correspond to $\mathrm{sp}^{2}$-hybridization, the contribution of the $S$ atom to the $\pi$-system does not appear to be significant based on the small bond angle [C1-S1-C12 99.9(1) ${ }^{\circ}$. Short intramolecular contacts are once again present due to the

Table 2. Selected bond distances $(\AA)$ and bond angles $\left(^{\circ}\right)$ for $\mathbf{4}, \mathbf{5}$ and 8

\begin{tabular}{llll}
\hline Compound 4 & & & \\
S1-C9 & $1.651(3)$ & C9-O1-C1 & $121.0(2)$ \\
O1-C9 & $1.357(3)$ & N1-C9-O1 & $109.7(2)$ \\
O1-C1 & $1.408(3)$ & N1-C9-S1 & $126.7(2)$ \\
N1-C9 & $1.322(3)$ & O1-C9-S1 & $123.6(2)$ \\
Compound 5 & & & \\
S1-C12 & $1.660(3)$ & C12-O1-C1 & $121.8(2)$ \\
O1-C12 & $1.363(3)$ & N1-C12-O1 & $110.2(2)$ \\
O1-C1 & $1.407(3)$ & N1-C12-S1 & $125.2(2)$ \\
N1-C12 & $1.321(3)$ & O1-C12-S1 & $124.5(2)$ \\
Compound 8 & & & \\
O1-C12 & $1.210(2)$ & C1-S1-C12 & $99.9(1)$ \\
S1-C12 & $1.802(2)$ & O1-C12-N1 & $124.4(2)$ \\
S1-C1 & $1.780(2)$ & O1-C12-S1 & $122.0(2)$ \\
N1-C12 & $1.341(3)$ & N1-C12-S1 & $113.6(2)$ \\
\hline
\end{tabular}

planarity of the thiocarbamoyl moiety [H13c-O1 $2.29 \AA$, and $\mathrm{H} 14 \mathrm{c}-\mathrm{S} 12.37 \AA$ ], which enforces the proximity of C13 and $\mathrm{C} 14$ to the $\mathrm{O} 1$ and $\mathrm{S} 1$ atoms, respectively. A list of selected bond lengths and angles for all compounds is presented in Table 2, and ORTEP diagrams of $\mathbf{5}$ and $\mathbf{8}$ are shown in Figures 2 and 3, respectively.

\section{Conclusions}

We have prepared and characterized new $O$-aryl and $S$-arylthiocarbamates which provide the entry point into

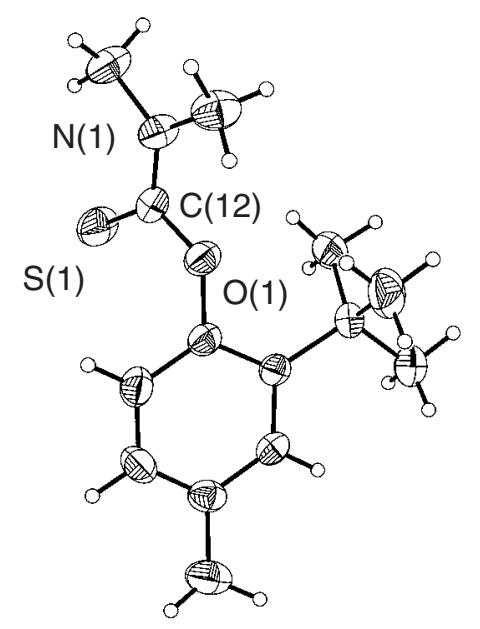

Figure 2. ORTEP view of $\mathbf{5}$. 


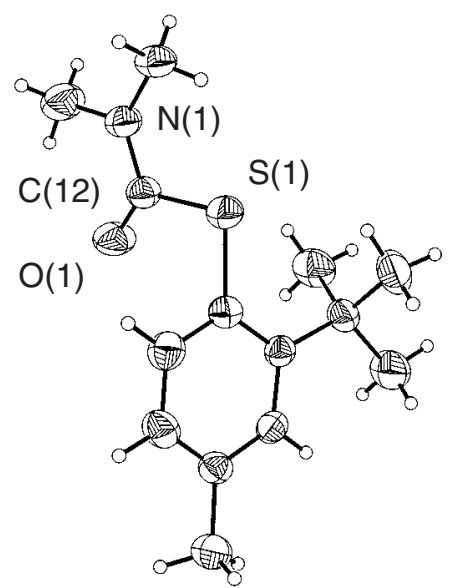

Figure 3. ORTEP view of $\mathbf{8}$.

the synthesis of 2,4-disubstituted thiols. Of the latter compounds, $\mathbf{1 1}$ and $\mathbf{1 2}$ are thiophenols that feature bulky substituents in the 2-position, which have not previously been reported perhaps due to the difficulty in their preparation. These thiols may prove useful as sterically encumbered thiolate ligands towards transition metals, and thus we are currently undertaking their synthesis on a larger scale. Having one of the activated ortho-positions available, this series of thiophenols can be incorporated into more complex structures in polydentate sulfur-based ligands with varying degrees of steric hindrance, depending on the identity of the substituent on the 2-position. ${ }^{11}$

\section{Experimental}

\section{General methods}

THF and dimethoxyethane were dried with sodium/ benzophenone, and distilled under a nitrogen atmosphere. All other solvents were used as received from commercial suppliers. 2,4-dimethylphenol (1), 2-tert-butyl-4methylphenol (2), 2-(1-adamantyl)-4-methylphenol (3), sodium hydride, and $N, N$-dimethylthiocarbamoyl chloride were purchased from Aldrich Chemical Co., and were used without further purification. IR spectra were obtained as chloroform solutions with a Perkin-Elmer 203-B spectrophotometer in the range $4000-400 \mathrm{~cm}^{-1} .{ }^{1} \mathrm{H}$ and ${ }^{13} \mathrm{C}$ NMR spectra were recorded on a JEOL Eclipse spectrometer at $20{ }^{\circ} \mathrm{C}$ operating at 300 and $75 \mathrm{MHz}$ respectively. Chemical shifts were reported using $\mathrm{Si}\left(\mathrm{CH}_{3}\right)_{4}$ as an internal standard. Electron-ionization mass spectrometry measurements were obtained with a JEOL JMS-AX505HA spectrometer. Elemental analyses were performed by Galbraith Laboratories (Knoxville, TN).

\section{Synthesis of organosulfur compounds}

For each kind of compound, i. e. $O$-arylthiocarbamate, $S$-arylthiocarbamate, and thiophenol, a detailed synthetic procedure is exemplified. The peaks that were specifically assigned in the NMR spectra are based on the numbering presented in Scheme 2.

2,4- $\mathrm{Me}_{2} \mathrm{C}_{6} \mathrm{H}_{3} \mathrm{OC}(\mathrm{S}) \mathrm{NMe}_{2}(4)$. In a two-necked round bottom flask equipped with a reflux condenser was dissolved 2,4-dimethylphenol (2.00 g, $16.40 \mathrm{mmol})$ in 75 $\mathrm{mL}$ of anhydrous dimethoxyethane under a nitrogen atmosphere. While the colorless solution was being vigorously stirred, solid $\mathrm{NaH}(0.43 \mathrm{~g}, 18.00 \mathrm{mmol})$ was added in small portions. Evolution of gas was observed $\left(\mathrm{H}_{2}\right)$, and the reaction mixture was allowed to stir until gas evolution subsided. $\mathrm{N}, \mathrm{N}$-dimethylthiocarbamoyl chloride ( $2.22 \mathrm{~g}, 18.00 \mathrm{mmol}$ ) was then added, and the mixture was heated to reflux for $24 \mathrm{~h}$. After cooling to room temperature, the mixture was quenched with $30 \mathrm{~mL}$ of water, and the organic phase was diluted with $30 \mathrm{~mL}$ of diethylether. The phases were separated with a separatory funnel, and the aqueous phase was washed with $3 \times 20 \mathrm{~mL}$ of diethylether. The combined organic phases were washed with distilled water $(30 \mathrm{~mL})$, a saturated $\mathrm{Na}_{2} \mathrm{CO}_{3}$ solution $(30 \mathrm{~mL})$, and were finally dried with anhydrous $\mathrm{Na}_{2} \mathrm{SO}_{4}$. The crude yellow solid obtained after filtration and evaporation of volatile materials was purified by column chromatography on silica gel by eluting with $\mathrm{CH}_{2} \mathrm{Cl}_{2}$; colorless crystals, $(1.72 \mathrm{~g}, 50 \%)$; $\mathrm{mp} 59-62{ }^{\circ} \mathrm{C}$; IR $\left(\mathrm{CHCl}_{3}\right)$ $v_{\max } / \mathrm{cm}^{-1}:$ 2987, 2928, 2870, $1536(\mathrm{C}=\mathrm{S}), 1499,1398$, 1291, 1194, 1144; ${ }^{1} \mathrm{H} \mathrm{NMR}\left(\mathrm{CDCl}_{3}, 300 \mathrm{MHz}\right): \delta 7.03(\mathrm{~d}$, $\left.{ }^{3} J 7.68 \mathrm{~Hz}, 1 \mathrm{H}, \mathrm{H}_{5}\right), 7.01\left(\mathrm{~s}, 1 \mathrm{H}, \mathrm{H}_{3}\right), 6.86\left(\mathrm{~d},{ }^{3} J 7.68 \mathrm{~Hz}, 1\right.$ $\left.\mathrm{H}, \mathrm{H}_{6}\right), 3.45$ (s, $3 \mathrm{H}, \mathrm{NCH}_{3}$ ), 3.34 (s, $3 \mathrm{H}, \mathrm{NCH}_{3}$ ), 2.32 (s, $3 \mathrm{H}$,<smiles></smiles><smiles>Cc1ccc(OC(=S)N(C)C)c(C(C)(C)C)c1</smiles><smiles>Cc1ccc(OC(=S)N(C)C)c(C23CC4CC(CC(C4)C2)C3)c1</smiles>

Scheme 2. Numbering scheme employed in NMR assignments. 
$\left.\mathrm{ArCH}_{3}\right), 2.15$ (s, $\left.\left.3 \mathrm{H}, \mathrm{ArCH}\right)_{3}\right) ;{ }^{13} \mathrm{C}\left\{{ }^{1} \mathrm{H}\right\} \mathrm{NMR}\left(\mathrm{CHCl}_{3}, 75\right.$ $\mathrm{MHz}$ ): $\delta 187.44\left(\mathrm{C}_{8}\right), 150.37$ (Ar), $135.62(\mathrm{Ar}), 131.67$ (Ar), 130.29 (Ar), 127.33 (Ar), 122.57 (Ar), $43.25\left(\mathrm{NCH}_{3}\right), 38.50$ $\left(\mathrm{NCH}_{3}\right), 20.93\left(\mathrm{ArCH}_{3}\right), 16.26\left(\mathrm{ArCH}_{3}\right) ; \mathrm{m} / \mathrm{z} 209\left(\mathrm{M}^{+}, 68 \%\right)$, 137 (24), 121 (11), 105 (14), 88 (100), 72 (87). Found: C, 63.55; H, 7.60; N, 6.54. Calc. for $\mathrm{C}_{11} \mathrm{H}_{15} \mathrm{NOS}$ : C, 63.12; $\mathrm{H}$, $7.22 ; \mathrm{N}, 6.69 \%$.

2- ${ }^{t} \mathrm{Bu}-4-\mathrm{MeC}_{6} \mathrm{H}_{3} \mathrm{OC}(\mathrm{S}) \mathrm{NMe}_{2}(5)$. Colorless crystals, (2.18 g, 53\%); mp 62-64 ${ }^{\circ} \mathrm{C}$; IR $\left(\mathrm{CHCl}_{3}\right) v_{\max } / \mathrm{cm}^{-1}: 3014$, 2962, 2866, 1710, 1526 (C=S), 1487, 1392, 1363, 1288, 1143, 1085, 1053, 925, 878; ${ }^{1} \mathrm{H} \mathrm{NMR}\left(\mathrm{CDCl}_{3}, 300 \mathrm{MHz}\right)$ : $\delta 7.18\left(\mathrm{~d},{ }^{4} J 2.07 \mathrm{~Hz}, 1 \mathrm{H}, \mathrm{H}_{3}\right), 7.03\left(\mathrm{dd},{ }^{3} J 8.25 \mathrm{~Hz},{ }^{4} J 2.07\right.$ $\left.\mathrm{Hz}, 1 \mathrm{H}, \mathrm{H}_{5}\right), 6.9$ (d, $\left.{ }^{3} J 8.25 \mathrm{~Hz}, 1 \mathrm{H}, \mathrm{H}_{6}\right), 3.49$ (s, $3 \mathrm{H}, \mathrm{NCH}_{3}$ ), 3.39 (s, $\left.3 \mathrm{H}, \mathrm{NCH}_{3}\right), 2.34$ (s, $3 \mathrm{H}, \mathrm{ArCH}_{3}$ ), 1.33 (s, $9 \mathrm{H},{ }^{\mathrm{t}} \mathrm{Bu}$ ); ${ }^{13} \mathrm{C}\left\{{ }^{1} \mathrm{H}\right\} \mathrm{NMR}\left(\mathrm{CHCl}_{3}, 75 \mathrm{MHz}\right): \delta 188.18\left(\mathrm{C}_{8}\right), 150.31$ (Ar), 140.59 (Ar), 135.06 (Ar), 127.84 (Ar), 127.02 (Ar), 125.08 (Ar), $43.36\left(\mathrm{NCH}_{3}\right), 38.82\left(\mathrm{NCH}_{3}\right), 34.44\left(\mathrm{ArCH}_{3}\right)$, $30.76\left(\mathrm{C}_{12}\right), 21.29\left(\mathrm{C}_{11}\right) ; \mathrm{m} / \mathrm{z} 251\left(\mathrm{M}^{+}, 31 \%\right), 194(28), 163$ (1), 145 (6), 88 (100), 72 (47). Found: C, 67.09; H, 8.53; N, 5.22. Calc. for $\mathrm{C}_{14} \mathrm{H}_{21} \mathrm{NOS}: \mathrm{C}, 66.89 ; \mathrm{H}, 8.42 ; \mathrm{N}, 5.57 \%$.

2-(1-Ad)-4- $\mathrm{MeC}_{6} \mathrm{H}_{3} \mathrm{OC}(\mathrm{S}) \mathrm{NMe}_{2}(\mathbf{6})$. Colorless crystals, (4.92 g, 91\%); mp 169-172 ${ }^{\circ} \mathrm{C}$; IR $\left(\mathrm{CHCl}_{3}\right) v_{\max } / \mathrm{cm}^{-1}: 2905$, 2851, 2739, 2668, 1553 (C=S), 1493, 1451, 1392, 1285, 1249, 1196, 1133, 1044, 813, 757; ${ }^{1} \mathrm{H}$ NMR ( $\left.\mathrm{CDCl}_{3}, 300 \mathrm{MHz}\right): \delta$ 7.15 (s, $\left.1 \mathrm{H}, \mathrm{H}_{3}\right), 6.99$ (d, $\left.{ }^{3} \mathrm{~J} 7.98 \mathrm{~Hz}, 1 \mathrm{H}, \mathrm{H}_{5}\right), 6.88$ (d, ${ }^{3} \mathrm{~J} 7.98$ $\left.\mathrm{Hz}, 1 \mathrm{H}, \mathrm{H}_{6}\right), 3.51$ (s, $3 \mathrm{H}, \mathrm{NCH}_{3}$ ), 3.42 (s, $\left.3 \mathrm{H}, \mathrm{NCH}_{3}\right), 2.34$ (s, 3 $\mathrm{H}, \mathrm{ArCH}_{3}$ ), 2.07 (s, $3 \mathrm{H}, \mathrm{H}_{13}$ ) 2.02 (s, 6 H, Ad), 1.73 (m, 6 H, Ad); ${ }^{13} \mathrm{C}\left\{{ }^{1} \mathrm{H}\right\} \mathrm{NMR}\left(\mathrm{CHCl}_{3}, 75 \mathrm{MHz}\right): \delta 188.28\left(\mathrm{C}_{8}\right), 150.62$ (Ar), 140.74 (Ar), 135.21 (Ar), 127.79 (Ar), 126.85 (Ar), 125.35 (Ar), $43.51\left(\mathrm{NCH}_{3}\right), 41.62$ (Ad), $38.97\left(\mathrm{NCH}_{3}\right), 37.04$ (Ad), $36.72\left(\mathrm{ArCH}_{3}\right), 29.01$ (Ad), 21.41 (Ad); m/z 330 (M+, 96\%), 257 (21), 88 (100), 72 (48). Found: C, 72.67; H, 8.51; N, 3.98. Calc. for $\mathrm{C}_{20} \mathrm{H}_{27} \mathrm{NOS}$ : C, 72.90; H, 8.26; N, 4.25\%.

2,4-Me $\mathrm{C}_{6} \mathrm{H}_{3} \mathrm{SC}(\mathrm{O}) \mathrm{NMe}_{2}$ (7). Yellow crystals, (1.23 g, 34\%); mp 33-34 ${ }^{\circ} \mathrm{C}$; IR $\left(\mathrm{CHCl}_{3}\right) v_{\max } / \mathrm{cm}^{-1}: 2926,2827$, $1654(\mathrm{C}=\mathrm{O}), 1479,1441,1367,1261,1100,1057 ;{ }^{1} \mathrm{H}$ NMR $\left(\mathrm{CDCl}_{3}, 300 \mathrm{MHz}\right): \delta 7.34\left(\mathrm{~d},{ }^{3} J 7.71 \mathrm{~Hz}, 1 \mathrm{H}, \mathrm{H}_{5}\right), 7.11$ (s, $\left.1 \mathrm{H}, \mathrm{H}_{3}\right), 7.00\left(\mathrm{~d},{ }^{3} \mathrm{~J} 7.71 \mathrm{~Hz}, 1 \mathrm{H}, \mathrm{H}_{6}\right), 3.11$ (br, s, $3 \mathrm{H}, \mathrm{NCH}_{3}$ ), 3.02 (br, s, $3 \mathrm{H}, \mathrm{NCH}_{3}$ ), 2.37 (s, $3 \mathrm{H}, \mathrm{ArCH}_{3}$ ), 2.32 (s, $3 \mathrm{H}$, $\left.\mathrm{ArCH}_{3}\right) ;{ }^{13} \mathrm{C}\left\{{ }^{1} \mathrm{H}\right\} \mathrm{NMR}\left(\mathrm{CHCl}_{3}, 75 \mathrm{MHz}\right): \delta 166.83\left(\mathrm{C}_{8}\right)$, 142.74 (Ar), 140.01 (Ar), 136.97 (Ar), 131.46 (Ar), 127.24 (Ar), $124.66(\mathrm{Ar}), 36.88\left(\mathrm{NCH}_{3}\right), 21.21\left(\mathrm{ArCH}_{3}\right), 20.94$ $\left(\mathrm{ArCH}_{3}\right) ; \mathrm{m} / \mathrm{z} 209\left(\mathrm{M}^{+}, 10 \%\right), 80$ (40), 137 (28), 124 (60), 105 (36), 91 (65), 83 (36), 71 (48), 57 (100), 43 (79), 28 (65), 18 (35). Found: C, 63.66; H, 7.06; N, 6.53. Calc. for $\mathrm{C}_{11} \mathrm{H}_{15} \mathrm{NOS}$ : C, 63.12; H, 7.22; N, 6.69\%.

$2{ }^{t} \mathrm{Bu}-4-\mathrm{MeC}_{6} \mathrm{H}_{3} \mathrm{SC}(\mathrm{O}) \mathrm{NMe}_{2}(\mathbf{8})$. Colorless crystals, (1.48 g, 46\%); mp 79-80 ${ }^{\circ} \mathrm{C}$; IR $\left(\mathrm{CHCl}_{3}\right) v_{\max } / \mathrm{cm}^{-1}: 3010$, 2957, 2862, 1653 (C=O), 1594, 1474, 1363, 1259, 1096, 1041, 907; ${ }^{1} \mathrm{H} \mathrm{NMR}\left(\mathrm{CDCl}_{3}, 300 \mathrm{MHz}\right): \delta 7.34$ (d, ${ }^{3} J 7.98$ $\left.\mathrm{Hz}, 1 \mathrm{H}, \mathrm{H}_{6}\right), 7.27$ (s, $\left.1 \mathrm{H}, \mathrm{H}_{3}\right), 7.04\left(\mathrm{~d},{ }^{3} \mathrm{~J} 7.98 \mathrm{~Hz}, 1 \mathrm{H}, \mathrm{H}_{5}\right.$ ),
3.08 (br, s, $6 \mathrm{H}, \mathrm{NCH}_{3}$ ), 2.35 (s, $\left.3 \mathrm{H}, \mathrm{Ar}\right), 1.46$ (s, $9 \mathrm{H},{ }^{\mathrm{t}} \mathrm{Bu}$ ); ${ }^{13} \mathrm{C}\left\{{ }^{1} \mathrm{H}\right\}$ NMR $\left(75 \mathrm{MHz}, \mathrm{CHCl}_{3}\right): \delta 167.57\left(\mathrm{C}_{8}\right), 152.52$ (Ar), 141.26 (Ar), 139.41 (Ar), 127.83 (Ar), 127.32 (Ar), 123.95 (Ar), $36.99\left(\mathrm{NCH}_{3}\right), 36.30\left(\mathrm{ArCH}_{3}\right), 30.97\left(\mathrm{C}_{12}\right)$, $21.65\left(\mathrm{C}_{11}\right) ; \mathrm{m} / \mathrm{z} 251\left(\mathrm{M}^{+}, 25 \%\right), 194$ (19), 179 (3), 72 (100). Found: C, 67.30; H, 8.69; N, 5.24. Calc. for $\mathrm{C}_{14} \mathrm{H}_{21} \mathrm{NOS}$ : C, $66.89 ; \mathrm{H}, 8.42 ; \mathrm{N}, 5.57 \%$.

2-(1-Ad)-4- $\mathrm{MeC}_{6} \mathrm{H}_{3} \mathrm{SC}(\mathrm{O}) \mathrm{NMe}_{2}(\mathbf{9})$. Solid $6(0.25 \mathrm{~g}, 0.76$ $\mathrm{mmol}$ ) was dried under vacuum in a Schlenk flask for $1 \mathrm{~h}$. The flask was immersed in a sand bath and heated to $310^{\circ} \mathrm{C}$ for $2 \mathrm{~h}$, keeping the top of the flask wrapped with aluminum foil to maintain a uniform temperature. After cooling to room temperature, the products were dissolved in $20 \mathrm{~mL} \mathrm{CH}_{2} \mathrm{Cl}_{2}$, filtered, and concentrated by evaporation of volatile materials. The product was separated from starting material by column chromatography by eluting with $\mathrm{CH}_{2} \mathrm{Cl}_{2}$. In this manner $0.07 \mathrm{~g}$ of $\mathbf{6}$ were recovered and recycled, and $\mathbf{9}$ was obtained as an off-white solid (0.06 g, 23\%); mp 134-135 ${ }^{\circ} \mathrm{C}$; IR $\left(\mathrm{CHCl}_{3}\right) v_{\text {max }} / \mathrm{cm}^{-1}: 3011,2908,2852,1710,1655$ $(\mathrm{C}=\mathrm{O}), 1598,1451,1406,1365,1261,1170,1100,1066$, 1029, 910; ${ }^{1} \mathrm{H} \mathrm{NMR}\left(\mathrm{CDCl}_{3}, 300 \mathrm{MHz}\right): \delta 7.24$ (d, ${ }^{3} J 7.68$ $\left.\mathrm{Hz}, 1 \mathrm{H}, \mathrm{H}_{6}\right), 7.13$ (d, $\left.{ }^{4} J 1.38 \mathrm{~Hz}, 1 \mathrm{H}, \mathrm{H}_{3}\right), 6.94$ (dd, ${ }^{3} J 7.68$ $\mathrm{Hz},{ }^{4} \mathrm{~J} 1.38 \mathrm{~Hz}, 1 \mathrm{H}, \mathrm{H}_{5}$ ), 3.02 (br, s, $6 \mathrm{H}, \mathrm{NCH}_{3}$ ), 2.28 (s, $3 \mathrm{H}$, $\mathrm{ArCH}_{3}$ ), 2.12 (s, $6 \mathrm{H}, \mathrm{Ad}$ ), 2.02 (s, $3 \mathrm{H}, \mathrm{H}_{13}$ ), 1.69 (s, 6 H, Ad); ${ }^{13} \mathrm{C}\left\{{ }^{1} \mathrm{H}\right\} \mathrm{NMR}\left(\mathrm{CHCl}_{3}, 75 \mathrm{MHz}\right): \delta 166.64\left(\mathrm{C}_{8}\right), 151.30(\mathrm{Ar})$, 140.51 (Ar), 138.42 (Ar), 126.90 (Ar), 126.09 (Ar), 122.75 (Ar), $40.37\left(\mathrm{NCH}_{3}\right), 37.21\left(\mathrm{ArCH}_{3}\right), 36.00$ (Ad), 35.79 (Ad), 28.21 (Ad), 20.64 (Ad); m/z $330\left(\mathrm{M}^{+}, 14 \%\right), 257$ (33), 194 (13), 72 (100); Found: C, 73.22; H, 7.96; N, 4.03. Calc. for $\mathrm{C}_{20} \mathrm{H}_{27} \mathrm{NOS}$ : C, 72.90; H, 8.26; N, 4.25\%.

2,4-Me $\mathrm{C}_{6} \mathrm{H}_{3} \mathrm{SH}(10)$. Yellow liquid, (1.23 g, 55\%); $\mathrm{m} / \mathrm{z}$ $209\left(\mathrm{M}^{+}, 10 \%\right), 80$ (40), 137 (28), 124 (60), 105 (36), 91 (65), 83 (36), 71 (48), 57 (100), 43 (79), 28 (65), 18 (35).

$2{ }^{t} \mathrm{Bu}-4-\mathrm{MeC}_{6} \mathrm{H}_{3} \mathrm{SH}(11)$. In a Schlenk flask under a nitrogen atmosphere compound $\mathbf{8}(1.46 \mathrm{~g}, 5.80 \mathrm{mmol})$ was dissolved in $25 \mathrm{~mL}$ of anhydrous THF, and the flask was cooled in an ice bath. Solid $\mathrm{LiAlH}_{4}(0.44 \mathrm{~g}, 11.60 \mathrm{mmol})$ was added in small portions while the solution was vigorously stirred. The reaction mixture was stirred for $1 \mathrm{~h}$ while warmed to room temperature, and then heated to reflux overnight. After cooling to $0{ }^{\circ} \mathrm{C}$, the mixture was quenched with $3 \mathrm{~mol} \mathrm{~L}^{-1} \mathrm{HCl}$ until a $\mathrm{pH}$ of 2 was reached, and the organic phase was isolated with a separatory funnel. The aqueous phase was extracted with $3 \times 20 \mathrm{~mL}$ of diethylether, and the combined organic phases were washed with distilled water, dried with $\mathrm{Na}_{2} \mathrm{SO}_{4}$, filtered, and concentrated to dryness to obtain pure $11(0.66 \mathrm{~g}, 63 \%)$; yellow oil; IR $\left(\mathrm{CHCl}_{3}\right) v_{\max } / \mathrm{cm}^{-1}: 2962,2918,2871,2567$ (S-H), 1598,1477, 1456, 1396, 1364, 1251, 1214, 1121, 1049, 1021, 931, 901, 807, 758; ${ }^{1} \mathrm{H}$ NMR $\left(\mathrm{CDCl}_{3}, 300\right.$ $\mathrm{MHz}): \delta 7.17\left(\mathrm{~s}, 1 \mathrm{H}, \mathrm{H}_{3}\right), 7.12\left(\mathrm{~d},{ }^{3} J 7.68 \mathrm{~Hz}, 1 \mathrm{H}, \mathrm{H}_{6}\right), 6.84$ 
(d, ${ }^{3}$ J $7.68 \mathrm{~Hz}, 1 \mathrm{H}, \mathrm{H}_{5}$ ), 3.52 (s, 1 H, SH), 2.28 (s, $3 \mathrm{H}$, $\left.\mathrm{ArCH}_{3}\right), 1.46\left(\mathrm{~s}, 9 \mathrm{H},{ }^{\mathrm{t}} \mathrm{Bu}\right) ;{ }^{13} \mathrm{C}\left\{{ }^{1} \mathrm{H}\right\} \mathrm{NMR}\left(\mathrm{CHCl}_{3}, 75 \mathrm{MHz}\right)$ : $\delta$ 147.29(Ar), 135.32 (Ar), 133.55 (Ar), 127.92 (Ar), 127.17 (Ar), 126.39 (Ar), $35.98\left(\mathrm{ArCH}_{3}\right), 29.78\left(\mathrm{C}_{12}\right), 21.27\left(\mathrm{C}_{11}\right)$; $\mathrm{m} / \mathrm{z} 358\left(\left[\mathrm{M}_{2}\right]^{+}, 100 \%\right), 180\left(\mathrm{M}^{+}, 12\right), 163$ (43), $148(7)$, 137 (13), 123 (6), 105 (4), 55 (7). Found: C, 73.15; H, 9.11. Calc. for $\mathrm{C}_{11} \mathrm{H}_{16} \mathrm{~S}: \mathrm{C}, 73.28 ; \mathrm{H}, 8.94 \%$.

2-(1-Ad)-4- $\mathrm{MeC}_{6} \mathrm{H}_{3} \mathrm{SH}(12)$. Colorless thick oil, (0.03 g, $68 \%) ; \mathrm{IR}\left(\mathrm{CHCl}_{3}\right) v_{\max } / \mathrm{cm}^{-1}: 2906,2850,2677,2564(\mathrm{~S}-\mathrm{H})$, 1599, 1450, 1372, 1315, 1260, 1097, 1027, 908, 871, 804; ${ }^{1} \mathrm{H} \mathrm{NMR}\left(\mathrm{CDCl}_{3}, 300 \mathrm{MHz}\right): \delta 7.11\left(\mathrm{~s}, 1 \mathrm{H}, \mathrm{H}_{3}\right), 7.09\left(\mathrm{~d},{ }^{3} \mathrm{~J}\right.$ $\left.7.98 \mathrm{~Hz}, 1 \mathrm{H}, \mathrm{H}_{6}\right), 6.83$ (d, $\left.{ }^{3} \mathrm{~J} 7.98 \mathrm{~Hz}, 1 \mathrm{H}, \mathrm{H}_{5}\right), 3.57$ (s, $1 \mathrm{H}$, $\mathrm{SH}), 2.28\left(\mathrm{~s}, 3 \mathrm{H}, \mathrm{H}_{7}\right) 2.19$ (s, $\left.6 \mathrm{H}, \mathrm{Ad}\right), 2.12\left(\mathrm{~s}, 3 \mathrm{H}, \mathrm{H}_{13}\right), 1.78$ (s, $6 \mathrm{H}, \mathrm{Ad}) ;{ }^{13} \mathrm{C}\left\{{ }^{1} \mathrm{H}\right\} \mathrm{NMR}\left(\mathrm{CHCl}_{3}, 75 \mathrm{MHz}\right): \delta 147.42$ (Ar), 135.33 (Ar), 133.79 (Ar), 127.94 (Ar), 126.96 (Ar), 126.00 (Ar), $40.14(\mathrm{Ad}), 37.74\left(\mathrm{ArCH}_{3}\right), 36.78(\mathrm{Ad}), 29.08(\mathrm{Ad})$, $21.16(\mathrm{Ad}) ; \mathrm{m} / \mathrm{z} 514\left(\left[\mathrm{M}_{2}\right]^{+}, 8 \%\right), 258\left(\mathrm{M}^{+}, 100\right), 201$ (11), 161 (15), 149 (13), 135 (8), 91 (6), 79 (6), 55 (5); Found: C, 78.88; H, 8.97. Calc. for $\mathrm{C}_{17} \mathrm{H}_{22} \mathrm{~S}: \mathrm{C}, 79.01 ; \mathrm{H}, 8.58 \%$.

Crystallographic data collection and structure determination of compounds 4,5 , and 8

Single crystals were mounted at room temperature on a Bruker SMART diffractometer equipped with an Apex CCD area detector. Frames were collected by omega scans, and integrated with the Bruker SAINT software package ${ }^{12}$ using the appropriate unit cell. The structures were solved using the SHELXS-97 program, ${ }^{13}$ and refined by full-matrix least-squares on $\mathrm{F}^{2}$ with the SHELXL-97 program. ${ }^{14}$ Hydrogen atoms were calculated in ideal positions, and refined as riding, with a fixed $\mathrm{U}_{\text {iso }}=1.2 \mathrm{U}_{\mathrm{eq}}$ of the parent atom, and with C-H distances in the range 0.93-0.97 $\AA$. All non-hydrogen atoms were refined anisotropically.

\section{Acknowledgment}

The authors wish to thank DGAPA-UNAM for financial support through project IN247402, Professor T. Don Tilley for a generous gift of 2-(1-adamantyl)-4-methylphenol, and Simón Hernández-Ortega for crystallographic work.

\section{Supplementary Information}

Crystallographic data (excluding structure factors) for the structures reported in this paper have been deposited with the Cambridge Crystallographic Data Centre as supplementary publication no. CCDC 253728-253730. Copies of the data can be obtained, free of charge via www.ccdc.cam.ac.uk/conts/retrieving.html (or from the Cambridge Crystallographic Data Centre, CCDC, 12
Union Road, Cambridge CB2 1EZ, UK ; fax: +44 1223 336033; or e-mail: deposit@ccdc.cam.ac.uk).

\section{References}

1. Metzner, P.; Thuillier, A.; Sulfur Reagents in Organic Synthesis, Academic Press: London, 1994.

2. Stephan, D. W.; Nadasdi, T. T.; Coord. Chem. Rev. 1996, 147, 147.

3. Recent examples: Marin-Almazo, M.; Garcia-Gutierrez, D.; Gao, X.; Elechiguerra, J. L.; Kusuma, V. A.; Sampson, W. M.; Miki-Yoshida, M.; Dalton, A. B.; Escudero, R.; Jose-Yacaman, M.; Nano Lett. 2004, 4, 1365; Shimmin, R. G.; Schoch, A. B.; Braun, P. V. Langmuir 2004, 20, 5613.

4. For example: Harrop, T. C.; Mascharak, P. K.; Acc. Chem. Res. 2004, 37, 253; Esposito, B. P.; Najjar, R.; Coord. Chem. Rev. 2002, 232, 137. Rehder, D.; Coord. Chem. Rev. 1999, 182, 297; Holm, R. H.; Kennepohl, P.; Solomon, E. I.; Chem. Rev. 1996, 96, 2239.

5. Rao, P. V.; Bhaduri, S.; Jiang, J.; Holm, R. H.; Inorg. Chem. 2004, 43, 5833 .

6. Sellmann, D.; Hautsch, B.; Rösler, A.; Heinemann, F. W.; Angew. Chem., Int. Ed. 2001, 40, 1505; Sanakis, Y.; Power, P. P.; Stubna, A.; Munck, E.; Inorg. Chem. 2002, 41, 2690; Buyuktas, B. S.; Olmstead, M. M.; Power, P. P.; Chem. Commun. 1998, 1689.

7. Newman, M. S.; Karnes, H. A.; J. Org. Chem. 1966, 31, 3980.

8. Higgs, T. C.; Carrano, C. J.; Eur. J. Org. Chem. 2002, 3632.

9. Uchiro, H.; Kobayashi, S.; Tetrahedron Lett. 1999, 40, 3179.

10. Bandarage, U. K.; Simpson, J.; Smith, R. A.; Weavers, R. T.; Tetrahedron 1994, 50, 3463; Cossu, S.; De Lucchi, O.; Fabbri, D.; Valle, G.; Painter, G. F.; Smith, R. A. J.; Tetrahedron 1997, 53, 6073; Rao, P.; Enger, O.; Graf, E.; Hosseini, M. W.; De Cian, A.; Fischer, J.; Eur. J. Inorg. Chem. 2000, 1503; Kane, V. V.; Gerdes, A.; Grahn, W.; Ernst, L.; Dix, I.; Jones, P. G.; Hopf, H.; Tetrahedron Lett. 2001, 42, 373; Castillo, I.; FloresFigueroa, A.; Hernández-Ortega, S.; Acta Crystallogr., Sect. C: Cryst. Struct. Commun. 2003, C59, o577.

11. Flores-Figueroa, A.; Castillo I.; Abstracts of the $27^{a}$ Reunião Anual da Sociedade Brasileira de Química, Salvador, Brazil, 2004.

12. Bruker AXS, SAINT Software Reference Manual v. 6.23, Madison, WI, 2002.

13. Sheldrick, G. M.; SHELXS-97. Crystal Structure Solution, Version 97-1, Institut Anorg. Chemie, University of Gottingen, Germany, 1990.

14. Sheldrick, G. M.; SHELXL-97. Crystal Structure Refinement, Version 97-1, Institut Anorg. Chemie, University of Gottingen, Germany, 1997. 